\title{
POTENSI BAKTERI PELARUT P DAN PENAMBAT N RHIZOSFER KELAPA SAWIT GAMBUT SAPRIK
}

\section{Oil Palm Rhizozfer Phosphat Solubilizing and Diazotrof potency in Saprict Peat}

\author{
Ida Nur Istina ${ }^{{ }^{1}}{ }$, Happy Widiastuti ${ }^{2}$ dan Benny Joy ${ }^{3}$ \\ ${ }^{1}$ Balai Pengkajian Teknologi Pertanian Riau, Jl.Kaharudin Nasution No. 341 Padang Marpoyan \\ Pekanbaru 10210 \\ ${ }^{2}$ Pusat Penelitian Perkebunan Nusantara, Jl. Taman Kencana No. 1, Bogor 16151, Jawa Barat - \\ Indonesia \\ ${ }^{3}$ Departemen Tanah Fakultas Pertanian Universitas Padjadjaran, Jl. Raya Bandung Sumedang \\ KM.21, Sumedang 45363 \\ Korespondensi :idanuristina@gmail.com
}

Diterima : 28 Agustus 2019 / Disetujui : 14 Juli 2020

\begin{abstract}
ABSTRAK
Pemanfaatan pupuk hayati sangat berpotensi untuk menurunkan input produksi pada budidaya kelapa sawit khususnya pupuk. Penelitian bertujuan untuk mendapatkan Bakteri Pelarut $\mathrm{P}$ dan Penambat $\mathrm{N}$ yang berpotensi sebagai bahan pupuk hayati dari rizosfer tanaman kelapa sawit. Penelitian dilakukan di lahan gambut saprik Kabupaten Pelalawan, Provinsi Riau dari bulan Juni sampai November 2014. Pengambilan sampel tanah dilakukan menggunakan bor gambut pada bagian rizosfer dengan kedalaman sampai $20 \mathrm{~cm}$. Isolasi dan karakterisasi dengan metode pure plate menggunakan media selektif $\mathrm{N}$ Ashby untuk penambatan $\mathrm{N}$ dan Pikovskaya untuk pelarutan $\mathrm{P}$, sedangkan analisis fiksasi $\mathrm{N}$ dan pelarutan $\mathrm{P}$ dilakukan menggunakan HPLC dan spektrofotometer di Laboratorium mikrobiologi PT. RPN. Hasil penelitian menunjukkan bahwa tanah gambut saprik berpotensi sebagai sumber isolat bakte $\mathrm{ri}$ pelarut $\mathrm{P}$ dan penambat $\mathrm{N}$ potensial. Jumlah isolat bakteri pelarut $\mathrm{P}$ yang berhasil diperoleh adalah 11 isolat sedangkan jumlah bakteri penambat $N$ non-simbiotik adalah 6 isolat. Isolat bakteri pelarut P potensial asal Sungai Ara dengan kemampuan melarutkan P 329,94 ppm; sedangkan bakteri penambat $\mathrm{N}$ non-simbiotik potensial adalah asal Kuala Panduk dengan

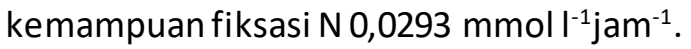

Kata kunci : bakteri, pemupukan, tanah gambut

\begin{abstract}
Utilization of biofertilizer is potential to decrease production inputs on oil palm cultivation, especially fertilizer expense. The research aimed to obtain Solubilizing P-Bacteria and NonSymbiotic Fixing $\mathrm{N}$ bacteria which potential as biological fertilizer from oil palm rhyzos phere. The research was conducted at Pelalawan sapric peat soil from June to November 2014. Soil samples were taken by using peat drill into $20 \mathrm{~cm}$ soil depth, while isolation and characterization used pure plate method by using the selective media $\mathrm{N}$ Ashby

Cyte this as: Istina, I, N., Widiastuti, H. \& Joy, B. (2020). Potensi bakteri pelarut P dan Penambat $N$ rhizosper kelapa sawit gambut saprik. Jurnal Agro, 7(1), 14-23. https://doi.org/10.15575/5776
\end{abstract}


for $\mathrm{N}$ fixation and Pikovskaya for $\mathrm{P}$ solubility. $\mathrm{N}$ fixation and $\mathrm{P}$ dissolution analyzed by using HPLC and spectrophotometer at PT. RPN microbiology laboratory. The results showed that sapric peat soil potentially utilize as microbial resource. The number of phosphate solubilizing bacteria isolates were 11 isolates, while the number of non-symbiotic nitrogen fixation bacteria inhibiting $\mathrm{N}$ Azotobacter sp. were 6 isolates. The potential isolate of $\mathrm{P}$-solubilizing bacteria was Sungai Ara origin with the ability to dissolve $\mathrm{P}$ about $329.94 \mathrm{ppm}$; while the potential of non-symbiotic $\mathrm{N}$-fixing bacteria was Kuala Panduk origin with $\mathrm{N}$ fixation ability $0.0293 \mathrm{mmoll}^{-1} \mathrm{~h}^{-1}$.

Keyword: bacteria, fertilizer, peat soil

\section{PENDAHULUAN}

Semakin menyempitnya luasan lahan produktif menyebabkan perluasan areal pertanian termasuk komoditas kelapa sawit mengarah pada lahan-lahan sub optimal seperti lahan gambut. Sampai tahun 2017 luasan perkebunan kelapa sawit di Indonesia meliputi 14 juta hektar (Direktorat Jendral Perkebunan, 2018), 1.7 juta hektar diantaranya diusahakan di lahan gambut (Rehman et al., 2015). Pengembangan pertanian dilahan gambut dihadapkan pada berbagai kendala diantaranya derajat kemasaman, rendahnya ketersediaan hara bagi tanaman, kadar abu $<2 \%$ (Masganti et al., 2017) serta tata air yang tidak terkontrol (Mey, 2016; Nugroho \& Sarwani, 2013). Selain itu juga adanya asam-asam fenolat yang bersifat racun bagi tanaman (Noor \& Masganti, 2016). Untuk meningkatkan produktivitas lahan gambut diantaranya melalui pengelolaan tata air, pemadatan tanah, dan pemupukan.

Aplikasi pemupukan anorganik secara terus menerus dapat mengakibatkan menurunnya tingkat kesuburan tanah, keragaman biota tanah, rentannya tanaman terhadap serangan hama dan penyakit serta pencemaran produk pertanian yang berdampak pada kesehatan manusia (Savci, 2012), dan menyebabkan penurunan efisiensi input produksi. Hajjam \& Cherkaoui
(2017) menyebutkan bahwa penggunaan pupuk kimia berbasis fosfat menyebabkan terjadnya polusi pada tanah dan air, dan apabila berinteraksi dengan unsur $\mathrm{Mg}, \mathrm{Ca}$, Fe akan mengendap dipermukaan tanah sehingga menyebabkan penurunan ketersediaan P. Upaya peningkatan efisiensi dan produktivitas lahan sub optimal adalah dengan pendayagunaan potensi biologi tanah yang berperanan dalam peningkatan ketersediaan dan transformasi hara penunjang pertumbuhan tanaman (Herman, 2013).

Pemanfaatan mikroba potensial sebagai pupuk hayati meningkatkan efisiensi input produksi khususnya pemupukan (Ajmal et al., 2018) melalui mekanisme interaksinya di rhizozfer untuk ketersediaan hara (Okur, 2018). Rhizozfer merupakan daerah yang dimana akar-akar tanaman berada dan melakukan aktivitasnya (Hartono \& Oslan, 2014; Himawan, 2018). Kondisi rhizozfer dipengaruhi oleh keberadaan bahan organik yang dikeluarkan oleh akar dan merupakan sumber energi bagi mikroba termasuk bakteri untuk metabolismenya serta penyediaan hara. Jenis hara yang diambil oleh akar tanaman menentukan kondisi fisik dan kimiawi tanah dan berpengaruh terhadap kelimpahan jumlah dan jenis mikroba yang tumbuh di bawahnya. (Susanti \& Surmaini, 2019) menyebutkan bahwa pada daerah rhizozfir bambu 
memiliki keragaman mikroba yang tinggi yang berperanan dalam pertumbuhan tanaman dan berperan sebagai pestisida hayati yang menekan serangan pathogen. Lebih lanjut Istina et al. (2015) menyebutkan bahwa lahan gambut saprik berpotensi sebagai sumber mikroba pelarut fosfat yang berpotensi untuk meningkatkan pertumbuhan tanaman kelapa sawit.

Penggunaan mikroba baik pemfiksasi $\mathrm{N}_{2}$ maupun pelarut $P$ dapat mengurangi kebutuhan pupuk $\mathrm{N}$ dan $\mathrm{P}$ sehingga mengurangi biaya produksi dan sangat sesuai untuk perkebunan rakyat dengan kemampuan finansial terbatas. Selain itu, penggunaan mikroba secara simultan juga meningkatkan daya dukung lahan terhadap mikroba antagonis yang dapat menekan perkembangan penyakit lahan (Jnawali et al., 2015). Penelitian ini bertujuan untuk mendapatkan mikroba pelarut $\mathrm{P}$ dan penambat $\mathrm{N}$ yang berpotensi sebagai bahan baku pupuk hayati yang mampu meningkatkan efisiensi input produksi khususnya pupuk yang dirasakan mahal dan tidak terjamin ketersediaannya di lokasi.

\section{BAHAN DAN METODE}

Penelitian telah dilaksanakan di Lahan Gambut yang ditanami Kelapa Sawit di Kabupaten Pelalawan Provinsi Riau dari bulan Juni sampai November 2014 dengan metode survey. Pengambilan sampel tanah dilakukan pada daerah perakaran kelapa sawit menggunakan bor gambut pada kedalaman $0-20 \mathrm{~cm}$ pada 9 titik pengamatan yang diambil secara acak pada tanah gambut saprik yang ada di sepanjang sungai (Ginting et al., 2006). Untuk mengantisipasi terjadinya perubahan jumlah dan jenis mikroba, masing-masing sampel dimasukkan ke dalam plastik dan disimpan dalam dalam kotak pendingin hingga ke laboratorium. Selanjutnya sampel tanah dibersihkan dari kotoran dan batuan serta ditimbang sebanyak $100 \mathrm{~g}$ untuk selanjutnya dilakukan isolasi menggunakan medium Ashby bebas $\mathrm{N}$ (bakteri penambat $\mathrm{N}$ ) dan pikovskaya (bakteri pelarut P) (Tabel1). Pengukuran sampel tanah dilakukan secara komposit di laboratorium tanah.

Tabel 1. Lokasi dan posisi pengambilan sampel tanah yang digunakan dalam penelitian

\begin{tabular}{|c|c|c|c|c|}
\hline Kode & Lokasi & \multicolumn{2}{|c|}{ Koordinat } & Ketinggian tempat \\
\hline T1 & Lubuk Ogong & $\mathrm{N} 00^{\circ} 10^{\prime} 00,2^{\prime \prime}$ & E $102^{\circ} 33^{\prime} 32,8^{\prime \prime}$ & 10 \\
\hline T2 & Muara Sako & N $00^{\circ} 16^{\prime} 46^{\prime} 8^{\prime \prime}$ & E $101^{\circ} 41^{\prime} 10,1^{\prime \prime}$ & 12 \\
\hline T 3 & Pangkalan Kerinci & N $00^{\circ} 21^{\prime} 28^{\prime} 1^{\prime \prime}$ & E $101^{\circ} 48^{\prime} 43,5^{\prime \prime}$ & 9 \\
\hline T4 & P.Kerinci & $\mathrm{N} 00^{\circ} 21^{\prime} 58^{\prime} 6^{\prime \prime}$ & E $101^{\circ} 52^{\prime} 13,4^{\prime \prime}$ & 13 \\
\hline T5 & Sungai Ara & N $00^{\circ} 08^{\prime} 13^{\prime} 4^{\prime \prime}$ & E $101^{\circ} 32^{\prime} 39,1^{\prime \prime}$ & 9 \\
\hline T 6 & S.Ara & N $00^{\circ} 08^{\prime} 13,4^{\prime \prime}$ & E $101^{\circ} 32^{\prime} 39,2^{\prime \prime}$ & 14 \\
\hline T7 & Kuala Panduk & N $00^{\circ} 12^{\prime} 16,2^{\prime \prime}$ & E $102^{\circ} 21^{\prime} 09,8^{\prime \prime}$ & 3 \\
\hline T 8 & Teluk Binjai & N $00^{\circ} 12^{\prime} 15,2^{\prime \prime}$ & E $102^{\circ} 21^{\prime} 09,5^{\prime \prime}$ & 3 \\
\hline T9 & Teluk Binjai B & N $00^{\circ} 10^{\prime} 55,0^{\prime \prime}$ & E $102^{\circ} 31^{\prime} 31,3^{\prime \prime}$ & 13 \\
\hline
\end{tabular}

Isolasi dan karakterisasi bakteri pemfiksasi $\mathrm{N}$ non simbiotik dan pelarut fosfat dilaksanakan di Laboratorium
Bioteknologi PT Riset Perkebunan Nusantara menggunakan metoda plate 
count pada mediun selektif agar N Ashby dan Pikovskaya yang mengandung $\mathrm{Ca}_{3} \mathrm{PO}_{4}$.

\section{Isolasi dan karakterisasi Bakteri Penambat} N

Sampel tanah sebanyak $2 \mathrm{~g}$ di diencerkan secara berseri dan ditumbuhkan pada media $\mathrm{N}$ Asby dan diinkubasikan pada suhu $30{ }^{\circ} \mathrm{C}$ dengan selama 4-7 hari hingga terbentuk pellicle pada permukaan media, selanjutnya pellicle yang terbentuk diisolasikan pada media $\mathrm{N}$ asbhy dengan metode gores dan dihitung pertumbuhannya.

Bakteri yang diindikasikan sebagai bakteri penambat $\mathrm{N}$ non simbiotik ditumbuhkan pada media NFB (Nitrogen Free Broth) semi cair selama 3-4 hari, (Saraswati et al., 2012). selanjutnya $2 \mathrm{ml}$ ekstrak bakteri dimasukkan dalam botolbotol kecil ukuran $15 \mathrm{ml}$ yang ditutup dengan dengan rapat menggunakan karet dan aluminium. Udara dalam botol dibuang $10 \%$ nya dengan syringe dan dengan alat yang sama digantikan dengan gas acetylene sebanyak $10 \%$ dan diinkubasikan selama 1 jam. Gas asetilen yang terbentuk diambil $50 \mu \mathrm{L}$ dan diinjeksikan ke dalam lubang Gas Chromatography-148 (GC) melalui kolom Porapak Q 80\% dan chromatopac C-R6A. Kondisi temperatur kolom $35^{\circ} \mathrm{C}$, injector $40^{\circ} \mathrm{C}$, dan detector (FID) $200^{\circ} \mathrm{C}$. Alat GC dikontrol oleh tekanan udara (100 Kpa), Hydrogen (100 Kpa) dan Nitrogen carrier/P (210 Kpa) dan Nitrogen carrier/M (200 Kpa). Parameter yang diamati meliputi warna koloni, morfologi koloni dan fiksasi $\mathrm{N}_{2}$ (ARA, mmoll-1 $\mathrm{jam}^{-1}$ ) (Hawkes, 2001).
Isolasi dan karakterisasi Bakteri Pelarut Fosfat

2 g sampel tanah di diencerkan dalam akuadest secara berseri hingga $10^{-8}$, selanjutnya diambil $1 \mathrm{ml}$ menggunakan mikro pipet dan dimasukkan ke dalam cawan petri berisi media selektif pikovskaya. Bakteri yang tumbuh selanjutnya ditumbuhkan pada Pelarutan $P$ diukur dengan melakukan analisis $\mathrm{P}$ Bray menggunakan spektrofoto meter pada panjang gelombang $700 \mathrm{~nm}$. Serta dihitung dengan menggunakan rumus (Saraswati et al., 2012)

\section{$\operatorname{Kadar} \mathrm{PO}_{4}(\mathrm{ppm})=\mathrm{ppm}$ kurva terlarut $\mathrm{x} f \mathrm{p}$}

Keterangan :

Kurva $=$ kadar contoh tanah yang diperoleh dari kurva hubungan antara deret standar dengan pembacaannya setelah koreksi blanko

$\mathrm{fp}=$ faktor pengenceran

Parameter yang diamati untuk bakteri $\mathrm{P}$ sebagai berikut: Warna koloni, Bentuk koloni, Diameter, Koloni (mm), Diameter Koloni+zone bening $(\mathrm{mm})$, Pelarutan $\mathrm{P}$ (Bray) ppm (Saraswati et al., 2012).

\section{HASIL DAN PEMBAHASAN}

Sampel tanah diambil dari rhizozfir kelapa sawit yang tumbuh pada tanah gambut saprik sebanyak 9 titik di sepanjang tepi sungai Kampar (Tabel 1). Ke sembilan sampel diambil dari 6 daerah dengan elevasi yang cukup beragam yakni dari 3 sampai $14 \mathrm{~m}$.

Karakteristik tanah yang diambil adal ah berwarna hitam kecoklatan dan bereaksi masam $(\mathrm{pH} 3,5)$ yang disebabkan oleh 
tingginya kandungan bahan organik dan asam-asam organik (Yondra \& Nelvia, 2017) yaitu asam humat dan fenolat. Hasil isolasi bakteri pelarut fosfat menggunakan media Pikovskaya dengan sumber $\mathrm{P}$ dari $\mathrm{Ca}_{3} \mathrm{PO}_{4}$, menunjukkan bahwa pada satu contoh tanah yang diambil dari rhizosfer tanaman kelapa sawit dapat dijumpai lebih dari 1 isolat, dengan warna merah, putih kuning dan kuning serta menghasilkan zona bening sebagai indikasi adanya pelarutan fosfat. Hal ini menunjukkan bahwa bakteri pelarut fosfat dapat hidup pada lahan gambut cukup beragam dan dipengaruhi oleh berbagai faktor diantaranya tersedianya substrat sebagai sumber bahan metabolismenya, $\mathrm{pH}$, suhu, kelembaban dan teksturtanah (Kiding et al., 2015).

Hasil penelitian (Putri et al., 2016) menyebutkan bahwa emisi $\mathrm{CO} 2$ yang merupakan hasil dari kegiatan metabolisme mikroba lebih banyak pada daerah rhizosfir dibandingkan dengan non rhizosfir. Karakteristik isolate pelarut $P$ yang ditemukan dirhizosfir tanaman kelapa sawit yang tumbuh pada tanah gambut saprik disajikan pada Tabel 2.

Tabel 2. Karakteristik isolate pelarut $\mathrm{P}$ hasil isolasi dari contoh tanah yang berhasil dimurnikan

\begin{tabular}{lccccccc}
\hline $\begin{array}{c}\text { Kode } \\
\text { isolat }\end{array}$ & $\begin{array}{c}\text { Diisolasi } \\
\text { dari } \\
\text { Pengenc. }\end{array}$ & $\begin{array}{c}\text { Inkubasi } \\
(\mathrm{hr})\end{array}$ & $\begin{array}{c}\text { Warna } \\
\text { koloni }\end{array}$ & $\begin{array}{c}\text { Bentuk } \\
\text { koloni }\end{array}$ & $\begin{array}{c}\text { Diam. } \\
\text { Koloni } \\
(\mathrm{mm})\end{array}$ & $\begin{array}{l}\text { Diameter } \\
\text { Koloni+zone } \\
\text { bening }(\mathrm{mm})\end{array}$ & $\begin{array}{l}\text { Jari jari } \\
\text { zona } \\
\text { bening } \\
(\mathrm{mm})\end{array}$ \\
\hline T1.1 & -4 & 2 & PK & Bulat & 3 & 5 & 1 \\
T1.3 & -4 & 2 & M & Bulat & 3 & 5 & 1 \\
T2.3 & -5 & 7 & PK & Bulat & 2 & 4 & 1 \\
T3.2 & -4 & 4 & PK & Bulat & 2 & 4 & 1 \\
T3.5 & -6 & 4 & PK & Bulat & 3 & 5 & 1 \\
T4.4 & -8 & 5 & PK & Bulat & 3 & 4 & 0,5 \\
T4.7 & -5 & 3 & PK & Bulat & 4 & 6 & 1 \\
T4.8 & -5 & 3 & PK & Bulat & 4 & 6 & 1 \\
T5.1 & -4 & 3 & PK & Bulat & 3 & 4 & 0,5 \\
T6.1 & -7 & 5 & PK & Bulat & 1,2 & 1,6 & 0,2 \\
T9.1 & -4 & 3 & K & Bulat & 5 & 10 & 2,5 \\
\hline Keterangan & 3K & & & & & & \\
\hline
\end{tabular}

Keterangan : $\mathrm{PK}=$ putih kuning; $\mathrm{M}=$ merah. $\mathrm{K}=$ kuning

Tabel 2 juga menunjukkan bahwa isolat yang berasal dari Teluk Binjai menunjukkan kemampuan yang paling tinggi. Pelarutan $P$ yang ditandai oleh terbentuknya zona bening pada medium Pikovskaya pada umumnya muncul pada hari ke 2 sampai hari ke 7, dengan kepadatan populasi bakteri pelarut fosfat Antara $10^{4}-10^{8}$. Warna koloni berkisar antara putih, kuning, dan merah dan sebagian besar berwarna putih dan kuning. T9 memiliki diameter koloni, dan diameter zona bening terbesar dibandingkan dengan isolat lainnya.

Populasi bakteri pelarut fosfat yang dijumpai di P. Kerinci (T4) cukup tinggi yaitu antara $10^{-4}-10^{-8}$. Daerah Pangkalan Kerinci mempunyai ketinggian tempat yang cukup tinggi yaitu $13 \mathrm{mdpl}$. Tabel 3 menunjukkan bahwa bakteri pelarut $P$ dijumpai pada elevasi dengan variasi tinggi. 
Tabel 3. Kemampuan melarutkan fosfat isolate dari masing-masing contoh tanah

\begin{tabular}{lcc}
\hline Kode isolat & $\begin{array}{c}\text { Diisolasi } \\
\text { dari }\end{array}$ & $\begin{array}{c}\text { Pelarutan P } \\
\text { (Bray) ppm }\end{array}$ \\
\hline T1.1 & -4 & 92,25 \\
T1.3 & -4 & 75,08 \\
T2.3 & -5 & 105,1 \\
T3.2 & -4 & 98,02 \\
T3.5 & -6 & 132,9 \\
T4.4 & -8 & 106,27 \\
T4.7 & -5 & 85,3 \\
T4.8 & -5 & 127,8 \\
T5.1 & -4 & 329,94 \\
T.6.1 & -7 & 92,0 \\
T.9.1 & -4 & 169,5 \\
\hline
\end{tabular}

Kemampuan pelarutan $\mathrm{P}$ di medium Pikovskaya dengan sumber $P$ adalah $\mathrm{Ca}_{3} \mathrm{PO}_{4}$, yang ditunjukkan oleh zona bening bervariasi antara 0,2 mm -1 mm dengan jumlah pelarutan antara 75,08 ppm329,94 ppm.

Pada isolat asal Sungai Ara (T.5.1) yang memiliki kerapatan $10^{4}$ memiliki kecepatan tumbuh dan diameter zona bening yang relative rendah, namun berdasarkan hasil analisis terhadap pelarutan fosfat menunjukkan kemampuan melarutkan fosfat paling tinggi terdapat pada isolate yang berasal dari lokasi Teluk Binjai B (T.9.1) yaitu 329,94 ppm; namun demikian jumlah $P$ terlarut oleh bakteri pelarut fosfat asal tanah gambut masih lebih rendah dibandingkan tanah PMK yaitu sebesar 473,6 ppm (Lestari et al., 2011).

Tingginya fosfat terlarut diduga dikarenakan banyaknya jenis dan jumlah asam organik yang dihasilkan oleh isolat Asam organik tersebut akan bereaksi FePO4, yang membentuk khelat (kompleks stabil) dengan kation-kation pengikat $P$ seperti Fe $3^{+}$(Yuli \& Muklis, 2018), sehingga dapat menurunkan reaktivitas ion-ion dan menyebabkan pelarutan secara efektif sehingga $\mathrm{P}$ yang terfiksasi dapat tersedia untuk tanaman; selain itu juga dimungkinkan oleh kesesuaian tumbuh bakteri (Respati et al., 2017). Bakteri akan tumbuh optimum pada $\mathrm{pH}$ netral.

Tabel 4. Isolat penambat $\mathrm{N}$ hasil isolasi dari masing-masing contoh tanah

\begin{tabular}{cccccc}
\hline $\begin{array}{c}\text { Kode } \\
\text { isolat }\end{array}$ & $\begin{array}{c}\text { Diisolasi } \\
\text { dari } \\
\text { pengenc. }\end{array}$ & $\begin{array}{c}\text { Inkubasi } \\
\text { (hari) }\end{array}$ & $\begin{array}{c}\text { Warna } \\
\text { koloni }\end{array}$ & $\begin{array}{c}\text { Morfologi } \\
\text { koloni }\end{array}$ & Fiksasi $\mathrm{N}_{2}$ (mmol///jam) \\
\hline T1.1 & -5 & 14 & $\mathrm{P}$ & $\mathrm{Bb}$ & 0,0203 \\
T1.2 & -4 & 5 & $\mathrm{P}$ & $\mathrm{Bb}$ & 0,0222 \\
T3 & -5 & 14 & $\mathrm{P}$ & $\mathrm{Bb}$ & 0,0206 \\
T5 & -4 & 5 & $\mathrm{P}$ & $\mathrm{Bb}$ & 0,0270 \\
T6 & -5 & 5 & $\mathrm{P}$ & $\mathrm{Bb}$ & 0,0193 \\
T7 & -5 & 5 & $\mathrm{P}$ & $\mathrm{Bb}$ & 0,0293 \\
\hline
\end{tabular}

Keterangan : $\mathrm{P}=$ Putih; $\mathrm{Bb}=$ Bulat berlendir

Bagaimanapun juga sebanyak 18 isolat bakteri pelarut $\mathrm{P}$ tidak berhasil dimurnikan. Karakter masing-masing isolat tersebut disajikan dalam Tabel 4. Koloni dijumpai isolat bakteri ini pada populasi yang relatif tinggi yaitu berkisar antara $10^{-4}$ sampai $10^{-8}$, berukuran kecil demikian pula pelarutan $\mathrm{P}$ di medium Pikovskaya yang 
ditunjukkan dengan adanya zona bening sangat tipis.

Hasil isolasi bakteri penambat $\mathrm{N}$ non symbiotic pada daerah rhizozfer tanaman kelapa sawit di lahan gambut kabupaten Pelalawan Provinsi Riau diperoleh 6 isolat yaitu berasal dari contoh 1, 3, 5, 6, dan 7 (Tabel 4). Bakteri penambat Nitrogen yang ditemukan di rhizosfir tanaman kelapa sawit lahan gambut Pelalawan Provinsi Riau pada umumnya berbentuk bulat dan berlendir. Hal ini seiring dengan hasil penelitian (Erfin et al., 2016) bahwa bakteri penambat Nitrogen Azotobacter pada umumnya memiliki sel yang berbentuk bulat dan umumnya merupakan jenis gram negatif.

Jumlah bakteri penambat Nitrogen yang ditemukan di lokasi penelitian jumlahnya lebih sedikit dibandingkan dengan hasil isolasi pada ekosistem hutan (Kaburuan et al., 2014), hal ini diduga dikaitkan dengan ketersediaan eksudat yang diperlukan oleh bakteri untuk tumbuh dan berkembang, selain itu keberadaan Azotobacter sp. tampaknya juga tidak dipengaruhi oleh elevasi lahan, karena dijumpai pada el evasi yang cukup beragam. Walaupun demikian bakteri penambat $\mathrm{N}$ tidak berhasil diisolasi dari sample T2 (Muara Sako), T4 (Pangkalan Kerinci B5), dan T8 (Teluk Binjai ) dan T9 (Teluk Binjai B).

Pada umumnya isolat tumbuh pada hari ke 5 dan beberapa isolat tumbuh setelah 14 hari inkubasi dan dijumpai pada pengenceran $10^{-5}$. Hasil ini menunjukkan bahwa populasi Azotobacter sp. pada rhizosfir kelapa sawit relatif lebih rendah dibandingkan dengan bakteri pelarut $P$. Selain itu, masa inkubasi juga jauh lebih lama dibandingkan dengan bakteri pelarut P.
Koloni bakteri penambat $\mathrm{N}$ yang ditemukan berwarna putih keruh, hal ini seiring dengan penemuan (Nurmas et al., 2014) yang menyebutkan bahwa ciri-ciri bakteri Azotobacter pada lahan ultisol adalah bentuk bulat, dan berwarna putih keruh, sedangkan Azotobacter yang ditemukan (Hartono \& Oslan, 2014) pada pertanaman jagung dan padi di Sulawesi berwarna transparan sampai kekuningan, lebih lanjut (Erfin et al., 2016) menemukan Azotobacter pada tanaman komba-komba memiliki bentuk oval dan berwarna berwarna merah muda lebih lanjut disebutkan bahwa perbedaan warna ini ditentukan oleh pewarnaan. Bakteri Azotobacter sp. juga dicirikan dengan adanya polisakarida yang berfungi untuk menahan kekeringan. Hasil analisis reduksi asetilen menunjukkan bahwa kemampuan penambatan $\mathrm{N}$ isolat hasil isolasi adalah berkisar antara, 0,0193 sampai 0,0293 $\mathrm{mmol} \mathrm{I}^{-1}$ jam $^{-1}$ dan isolat asal desa Kuala Panduk (T7) adalah isolat yang mempunyai kemampuan penambatan $\mathrm{N}$ tertinggi diikuti dengan isolat asal Sungai Ara (T5) meskipun jauh lebih rendah dibandingkan hasil penelitian Nurmas (2014) yaitu sebesar $2 \mathrm{mmol}$. Hal ini menunjukkan bahwa isolat asal Kuala Panduk (T7) dan Sungai Ara (T5) berpotensi sebagai bahan baku biofertiliser untuk mengurangi input produksi khususnya nitrogen dan toleran lahan masam (Muklis, 2020)

\section{SIMPULAN}

1. Jumlah isolat bakteri pelarut $P$ yang berhasil diperoleh adalah 11 isolat sedangkan sedangkan jumlah bakteri penambat N Azotobacter sp. adalah 6 isolat. 
2. Isolat bakteri pelarut fosfat asal Sungai Ara berwarna kuning, berbentuk bulat, diameter koloni dan zona bening $4 \mathrm{~mm}$ dengan kemampuan melarutkan P 329,94 ppm dan asal Teluk Binjai yang berwarna kuning, berbentuk bulat, diameter koloni dan zona bening $10 \mathrm{~mm}$ 169,5 ppm; sedangkan bakteri penambat $\mathrm{N}$ non simbiotik asal Kuala Panduk yang berwarna putih dengan morfologi bulat berlendir dengan kemampuan fiksasi $\quad \mathrm{N} \quad 0,0293 \quad \mathrm{mmoll}^{-1} \mathrm{jam}^{-1}$ berpotensi sebagai bahan aktif pupuk hayati

\section{UCAPAN TERIMA KASIH}

Ucapan terima kasih disampaikan kepada SMARTD melalui program KKP3N yang telah memberikan dana, Heri Widianto dan Jakoni yang telah membantu terlaksananya kegiatan penelitian.

\section{DAFTAR PUSTAKA}

Ajmal Maria, Hafiza lqra Ali, Rashid Saeed, Asna Aktar, Muniba Tahir, M.Z.M. \& A.A.(2018). Biofertilizer as an Alternative for Chemical Fertilizers. Research \& Reviews: Journal of Agriculture and Allied Sciences. [Online] 7 (1), 1-7. Available from: http://www.rroij.com/open-access/ biofertilizer-as-an-alternative-forchemical - fertilizers. . php ?aid=86649.

Direktorat Jendral Perkebunan (2018) Program Pembangunan Perkebunan. (2018).[Online] Available from: http://ditjenbun.pertanian.go.id.

Erfin, Sandiah, N. \& Malesi, L.(2016). Identifikasi bakteri Azospirillum dan Azotobacter pada rhizospher asal komb-komba (Chromolaena odorata ). Jitro. 3 (2).
Erni Susanti, Elza Surmaini, \& W.E. (2019). Parameter Iklim sebagai Indikator Peringatan Dini Serangan Hama Penyakit Tanaman. Sumberdaya lahan. 12 (1), 59-70.

Ginting, R.C.B., Saraswati, R. \& Husen, E. (2006). Mikroorganisme pelarut fosfat. Besar Litbang Sumberdaya Lahan Pertanian Badan Penelitian dan Pengembangan Pertanian: Bogor. 149.

Hajjam, Y. \& Cherkaoui, S. (2017). The influence of phosphate solubilizing microorganisms on symbiotic nitrogen fixation: Perspectives for sustainable agriculture. Journal of Materials and Environmental Science. 8 (3), 801-808.

Hawkes, C. (2001). Acetylene reduction method for measuring nitrogenase activity tested by Christine Hawkes. (2010, Juni 14). Retrieved from http://www.biosci.utexas.edu/IB/fac ulty/hawke s/lab/ proto cols/acetylene_r

Hartono dan Oslan Jumadi (2014) Seleksi dan Karakterisasi Bakteri Penambat Nitrogen Non Simbiotik Pengekskresi Amonium Pada Tanah Pertanaman Jagung (Zea mays L.) dan Padi ( Oryza sativa L.) Asal Kabupaten Barru, Sulawesi Selatan, Indonesia. Jurnal Sainsmat. [Online] III (2), 143153. Available from: http://ojs.unm .ac.id/index.php/sainsmat.

Herman, M. dan D.P (2013). Pengaruh Mikroba Pelarut Fosfat Terhadap Pertumbuhan Dan Serapan Hara P Benih Kakao ( Theobroma Cacao L.) Effect Of Phosphate Solubilizing Microbes On The Growth And. Balittri. 129-138.

Himawan, A.H.G.M. (2018). Deteksi Bakteri Rhizosfer Kelapa Sawit Di Tanah Mineral Menggunakan Metode PcrRisa. Agroista. 02 (01), 73-82. 
Istina Ida Nur, Happy Widiastuty, Benny Joy \& Merry Antralina.(2015). Phosphate Solubilizing Microbe from Saprist Peat Soil and Their Potency to Enhance Oil Palm Growth and $P$ Uptake. Procedia Food Science. V3. DO.10.1016/j.profo.2015.01.047

Jnawali A.D., Roshan Babu Ojha, S.M. (2015). Evaluation of Maize Nutrient Contents in a Maize/Cowpea Intercropping Systems in South Africa. Advances in Plants \& Agriculture Research. [Online] 2 (6), 250-253. Available from: doi:10.15406/apar.2015.02.00069.

Kaburuan R., Hapsoh \& Gusmawartati .(2014). Isolasi Dan Karakterisasi Bakteri Penambat Nitrogen NonSimbiotik Tanah Gambut Cagar Biosfer Giam Siak Kecil-Bukit Batu. 5 (1), 35-39.

Kiding, A., Khotimah, S. \& Linda, R. (2015). Karakterisasi dan Kepadatan Bakteri Nitrifikasi pada Tingkat Kematangan Tanah Gambut yang Berbeda Di Kawasan Hutan Lindung Gunung Ambawang Kabupaten Kubu Raya. Jurnal Protobion. 4(1), 17-21.

Lestari, W., Linda, M. \& Martina, A. (2011). Kemampuan Bakteri Pelarut Fosfat Isolat Asal Sei Garo dalam Penyediaan Fosfat Terlarut dan Serapannya pada Tanaman Kedelai (Capability of Phosphate Solubilizing Bacteria from Sei Garo in Soluble Phosphate and its Uptake by Soybean). Biospecies. [Online] 4 (2), 15. Available from: doi:10.7498/aps.64.064206.

Lestari Y. \& Muklis .(2018). Prospect of phosphate solubilizing micro organisms for acid sulphate soil bioremediation. Proceeding of International Workshop And Seminar Innovation of EnvironmentalFriendly Agricultural Technology Supporting Sustainable Food Self-
Sufficiency. 265-274

Masganti, Khairil Anwar, Maulia Aries Susanti. (2017). Potensi dan Pemanfaatan Lahan Gambut Dangkal untuk Pertanian. Jurnal Sumberdaya Lahan Vol. 11 No. 1, Juli 2017; 43-52

Mey Saragih, J. (2016). Pengelolaan Lahan Gambut di Perkebunan Kelapa Sawit di Riau Management of Peatland at Oil Palm Plantation in Riau. Bul. Agrohorti. 4 (3).

Muklis .(2020). Mikroba Tanah Rawa dan Pemanfaatannya sebagai Biofertiliser dan Bioremidiator. http://www. repository, pertanian.go.id $>$ bitstream >handle>12Microb : 174-197

Noor Muhammad \& Masganti, F.A. (2016). Lahan gambut Indonesia Pembentukan, karakteristik, dan potensi mendukung ketahanan pangan (Edisi revisi) (English translation: Peatland Indonesia Formation, characteristics, and potential to support food security (reviewed edition)). Agus, FA, Markus Anda, Ali Jamil, M. (ed.) Revisi II,. Jakarta, IAARD Pres.

Nugroho, K. dan \& Sarwani, M. (2013). Characterizing the cultivated lowland peat soils in two physiography positions in Kalimantan, Indonesia. [Online] 3 (7), 246-255. Available from: http://www.interesjournals. org/IRJAS.

Nurmas, A., Rahman, A. \& Khaeruni, D.A.N.A. (2014). Eksplorasi Dan Karakterisasi Azotobacter Indigenous Lokal Di Lahan Marjinal Exploration and Characterization of Indigenous Azotobacter for biofertilizer Development of Local Upland Rice of Marginal Land. Agroteknos. 4 (2), 128-134.

Okur, N. (2018). A Review: Bio-FertilizersPower of Beneficial Microorganisms 
in Soils. Biomedical Journal of Scientific and technical research. Volume 4 (4), 2. Available from: doi:10.26717/BJSTR.2018.04.001076

Putri, T., Syaufina, L. \& Anshari, G. (2016). Emisi Karbon Dioksida $\left(\mathrm{CO}_{2}\right)$ Rizosfer dan Non Rizosfer dari Perkebunan Kelapa Sawit (Elaeis guineensis) pada Lahan Gambut Dangkal. Jurnal Tanah dan Iklim. Volume 40 (1), 43-50. Available from: doi:10.2017/jti. v 40i1. 6174.

Rehman, S.A., Ur Rehman, Supiandi Sabiham, Untung Sudadi and Syaiful Anwar .(2015). Impacts of Oil Palm Plantations on Climate Change: A Review of Peat Swamp Forests' Conversion in Indonesia. Internat ional Journal of Plant \& Soil Science. Volume 4 (1), 1-17. Available from: doi:10.9734/IJPSS/ 2015/11848.

Respati, N.Y. Yulianti, E. \& Rakhmawati, A. .
.(2017). Kemampuan Pelarutan Fosfat Oleh Bakteri Termofilik Pada Variasi Suhu Dan Ph. 144-145. Jurnal Prodi Biologi. 6 (7), 423-430. Available from: http://journal.student.uny.ac.id/ojs/ ojs/index.php/biologi/article/ viewFile/ 7864/ 74

Saraswati, E. Husen, R.D.M. Simanungkalit. (2012). Metode Analisis Biologi Tanah. Badan Penelitian dan pengembang an Pertanian Kementerian Pertanian. 299 hal.

Savci, S. (2012). Investigation of Effect of Chemical Fertilizers on Environment. APCBEE Procedia. Volume 1, pp.287292. Available from: doi:10.1016/ j.apcbee.2012.03.047

Yondra \& Nelvia, W. (2017). Kajian Sifat Kimia Lahan Gambut Pada Berbagai Landuse. Jurnal Agric. Volume 29 (25), 103-112. ejournal.uksw.edu 